\title{
OPEN
}

\section{Publisher Correction: Anatomical study of the coffee berry borer (Hypothenemus hampei) using micro-computed tomography}

Ignacio Alba-Alejandre, Javier Alba-Tercedor \& Fernando E. Vega

Correction to: Scientific Reports https://doi.org/10.1038/s41598-019-53537-z, published online 20 November 2019

In the original version of this Article, nine Supplementary Video files were omitted. This has been corrected in the HTML version of the Article; the PDF version was correct at the time of publication.

\begin{abstract}
(c) (i) Open Access This article is licensed under a Creative Commons Attribution 4.0 International Cicense, which permits use, sharing, adaptation, distribution and reproduction in any medium or format, as long as you give appropriate credit to the original author(s) and the source, provide a link to the Creative Commons license, and indicate if changes were made. The images or other third party material in this article are included in the article's Creative Commons license, unless indicated otherwise in a credit line to the material. If material is not included in the article's Creative Commons license and your intended use is not permitted by statutory regulation or exceeds the permitted use, you will need to obtain permission directly from the copyright holder. To view a copy of this license, visit http://creativecommons.org/licenses/by/4.0/.
\end{abstract}

(C) The Author(s) 2020 